\title{
Is Time Ripe for Hepatitis A Mass Vaccination?
}

\author{
UJJAL PodDaR* and Aathira RaVindRanath \\ Department of Pediatric Gastroenterology, Sanjay Gandhi Postgraduate Institute of Medical Sciences, Lucknow, India. \\ *ujjalpoddar@hotmail.com
}

$\mathrm{O}$ ne more "World Hepatitis Day" has just passed and amidst all the global attention that hepatitis $\mathrm{B}$ and $\mathrm{C}$ get, complicated disease course due to hepatitis A becomes an emerging battle in countries undergoing epidemiological transition from high to intermediate endemicity. Globally, hepatitis A accounts for 126 million cases of acute hepatitis and 35,245 deaths every year [1]. It is well known that hepatitis A has age-dependent clinical manifestations, being asymptomatic in early childhood and causing icteric illness and complications in adolescence and adulthood. In regions with high endemicity, hepatitis A causes asymptomatic infection in almost everyone during childhood thus conferring life-long immunity, whereas the low endemicity areas have low circulation of hepatitis A with a large vulnerable population not exposed to the virus due to better sanitation and hygiene. Therefore, hepatitis A is not a major public health problem in in high endemicity areas, except for local outbreaks. Holding a unique place in the epidemiology of hepatitis A are the intermediate endemicity areas, which have high circulation of hepatitis A but a fair number of the population have climbed up the socio-economic ladder rendering them susceptible to hepatitis A with a complicated course [2]. The World Health Organization suggests the following classification for endemicity - High: $\geq 90 \%$ seroprevalence by 10 years of age; intermediate: $<90 \%$ by 10 years and $\geq 50 \%$ by 15 years; low: $\geq 50 \%$ by 30 years and $<50 \%$ by 15 years; and very low: $<50 \%$ by 30 years [1]. As countries have a transition from high endemicity to intermediate endemicity, the number of clinically significant hepatitis A would paradoxically go up. Though there is paucity of large epidemiological studies, India is possibly in transit from high to intermediate endemicity as suggested by a study of 928 children that showed that the seroprevalence of hepatitis A is $50 \%$ in children aged 6 to 10 years [3]. In another laboratory surveillance data study, $25 \%$ cases of Hepatitis A disease occurred after 19 years of age [4]. In contrast, earlier studies showed seroprevalence of anti HAV IgG to be $84 \%$ by 6 years and $96 \%$ by 12 years of age [5]. Hence, this time of epidemiological shift in India is the most apt to examine hepatitis Arelated clinical illness with a fresh perspective.

In the study reported in this issue of Indian Pediatrics [6], hepatitis A virus (HAV) accounted for $48.6 \%$ of acute viral hepatitis (AVH), $46.5 \%$ of acute liver failure (ALF) and $14.6 \%$ of acute-on chronic liver failure (ACLF), which is almost similar to previous studies from India that have shown that $\mathrm{HAV}$ is the etiology in 65 to $76 \%$ of all $\mathrm{AVH}, 51 \%$ of ALF and $17 \%$ of ACLF [7-10]. Among those with AVH, $41 \%$ had atypical features and required hospitalization [6]. In two other studies, $30 \%$ of all HAV cases had atypical features [7,11]. The most common atypical feature reported in this study [6], and the study reported from our center [11], was prolonged cholestasis. It is imperative to be aware of other serious complications like intravascular hemolysis, hemophagocytic lymphohistiocytosis (HLH), acute pancreatitis and acute kidney injury, which need early recognition and therapy. HAV is notorious for being the commonest cause of ALF in children in the developing world as is evident from this study [6] as well as previous studies [9]. This is in stark contrast to the western literature where HAV contributes only $1 \%$ to pediatric ALF etiology [12]. The case fatality ratio of HAV infection is estimated to range between $0.1 \%$ to $2 \%$ depending on the age; however, mortality rate of ALF due to HAV soars to $30-50 \%$ [9]. This assumes further importance in our country where affordability for specialized intensive care and liver transplantation is limited to very few.

The second part of the study [6] showed that $16 \%$ of children aged 10 to 18 years and $10 \%$ of adults aged 18 to 30 years were still negative for Anti-HAV IgG, which is a reflection of the increasingly susceptible older population. A previous study from New Delhi documented the seroprevalence of HAV to reach $97 \%$ by 12 to 18 years of age, irrespective of socioeconomic status [13]. But more recent studies are testimony to the drift in peak seroprevalence towards older age groups [3]. However, we should also be aware of the fact that this study [6] was based on hospital-based data collected from a tertiary-care paid facility in New Delhi and seroprevalence data of this 
study are unlikely to represent the community data as higher strata of society - who are likely to be seronegative - were overrepresented. Extrapolating these results to the rest of the country would be a treacherous path to tread as India has a heterogenous population with great variability in socioeconomic strata. Recommending inclusion of HAV vaccine in the universal immunization schedule would also be too premature based on the present study as the sample is not representative of healthy children in the population. The decision between targeted immunization and universal immunization ought to be taken based on the endemicity pattern. Cost-effectiveness of universal hepatitis A vaccination is undoubtedly evident in middle-income countries with intermediate endemicity, and targeted immunization is better suited for low endemicity regions [14]. The heterogenous population is the biggest hurdle in determining the pan-Indian endemicity pattern, and we need to understand that one shoe does not fit all. With limited healthcare funding, the task ahead for us would be to determine the cost-effectiveness of implementing universal vaccination against hepatitis $\mathrm{A}$, and the stepping stone for that would be a region-wise endemicity pattern assessment with robust seroprevalence data.

Funding: None; Competing interest: None stated.

\section{REFERENCES}

1. WHO Position Paper on Hepatitis A Vaccines - June 2012. Wkly Epidemiol Rec. 2012; 87:261-76

2. Aggarwal R, Goel A. Hepatitis A: Epidemiology in resource-poor countries. Curr Opin Infect Dis. 2015;28:488-96.

3. Arankalle V, Mitra M, Bhave S, Ghosh A, Balasubramanian $\mathrm{S}$, Chatterjee S, et al. Changing epidemiology of hepatitis A virus in Indian children. Dovepress. 2014;4:7-13.

4. Murhekar MV, Ashok M, Kanagasabai K, Joshua V, Ravi $\mathrm{M}$, Sabarinathan R, et al. Epidemiology of hepatitis A and hepatitis $\mathrm{E}$ based on laboratory surveillance data-India,
2014-2017. Am J Trop Med Hyg. 2018;99:1058-61.

5. Mohanavalli B, Dhevahi E, Menon T, Malathi S, Thyagarajan SP. Prevalence of antibodies to hepatitis A and hepatitis $\mathrm{E}$ virus in urban school children in Chennai. Indian Pediatr. 2003;40:328-31.

6. Sood V, Lal BB, Gupta E, Khanna R, Siloliya MK, Alam S. Hepatitis A virus-related pediatric liver disease burden and its significance in the Indian subcontinent. Indian Pediatr. 2019;56:741-44.

7. Poddar U, Thapa BR, Prasad A, Singh K. Changing spectrum of sporadic acute viral hepatitis in Indian children. J Trop Pediatr. 2002;48:210-3.

8. Kumar A, Yachha SK, Poddar U, Singh U, Aggarwal R. Does co-infection with multiple viruses adversely inûuence the course and outcome of sporadic acute viral hepatitis in children? J Gastroenterol Hepatol. 2006;21:1533-7.

9. Poddar U, Thapa BR, Prasad A, Sharma AK, Singh K. Natural history and risk factors in fulminant hepatic failure. Arch Dis Child. 2002;87:54-6.

10. Jagadisan B, Srivastava A, Yachha SK, Poddar U. Acute on chronic liver disease in children from the developing world: Recognition and prognosis. J Pediatr Gastroenterol Nutr. 2012;54:77-82.

11. Singh SK, Borkar V, Srivastava A, Mathias A, Yachha SK, Poddar U. Need for recognizing atypical manifestations of childhood sporadic acute viral hepatitis warranting differences in management. Eur J Pediatr. 2019;178:61-7.

12. Squires RH Jr, Shneider BL, Bucuvalas J, Alonso E, Sokol RJ, Narkewicz MR, et al. Acute liver failure in children: The first 348 patients in the pediatric acute liver failure study group. J Pediatr. 2006;148:652-8.

13. Acharya SK, Batra Y, Bhaktal B, Ojha B, Kaur K, Hazari S, et al. Sero epidemiology of hepatitis A virus infection among school children in Delhi and north Indian patients with chronic liver disease: Implications for $\mathrm{HAV}$ vaccination. J Gastroenterol Hepatol. 2003;18:822-7.

14. Suwantika AA, Yegenoglu S, Riewpaiboon A, Tu HA, Postma MJ. Economic evaluations of hepatitis A vaccination in middle-income countries. Expert Rev Vaccines. 2013;12:1479-94. 